\title{
Interactions of sialic acid with phosphatidylcholine liposomes studied by 2D NMR spectroscopy
}

\author{
Anna Timoszyk ${ }^{\bowtie}$ and Lidia Latanowicz \\ Laboratory of Biophysics, Department of Biotechnology, Faculty of Biological Sciences, University of Zielona Góra, Zielona Góra, Poland
}

\begin{abstract}
Biological membranes are complex systems which have attracted scientific interest for a long time and for various reasons. The sialic acid-liposome interactions at the molecular level depend on their hydro-lipophilic characteristics. The aim of the present study was to investigate the changes of conformation of the phospholipid (1,2-Diacyl-sn-glycero-3-phosphocholine) and sialic acid (2,8-( $\mathrm{N}$-acetylneuraminic acid $))$ molecules and the type of interactions induced by the sialic acid molecules on membrane-like systems (liposomes) by 2D NMR (TOCSY, HETCOR, ROESY). The nature of the interaction of sialic acid with the model membrane depends on the structure of the phospholipid headgroups and the hydration of membrane. In ROESY spectra was observed the absence of dipole-dipole couplings within the choline head, between headgroups and glycerol, and between glycerol and fatty acid chains. It indicates an increase of the membrane dynamics in the presence of sialic acid. Moreover, the conformation of sialic acid molecule is changed in the presence of liposomes, which depends on stereochemistry of the chemical groups of the carbon atoms C7 and C8, and oxygen 08. The observed differences between the ROESY spectra of free and liposome bound sialic acid may be a consequence of a changed orientation of the pyranose ring from trans to gauche in the presence of liposomes. The sialic acid penetrate into the phospholipid bilayer to a sufficient depth to allow the dipole interaction. The present result that the correlation signal was found only between the methyl protons from the acetyl group of sialic acid and the methylene tail of phospholipid molecule in the ROESY spectrum indicates that the opposite end of the sialic acid molecule stays in the aqueous phase without interacting with membrane molecules.
\end{abstract}

Key words: sialic acid, phospholipid membrane, 2D NMR, HETCOR, TOCSY, ROESY

Received: 26 August, 2012; revised: 25 June, 2013; accepted: 02 December, 2013; available on-line: 20 December, 2013

\section{INTRODUCTION}

Sialic acids are acidic 9-carbon sugars; the most commonly found are those derived from the 5-acetamido-Dglycero-D-galacto-2-nonulosonic acid ( $N$-acetylneuraminic acid, Neu5Ac) (Hartlieb et al., 2008; Bondioli et al., 2010). The sialic acids are intimately involved in a number of important physiological phenomena and disease states. Located at the terminus of numerous cell-surface oligosaccharides, sialic acids are ideally positioned to participate in the carbohydrate-protein interactions that mediate the recognition phenomena (Schauer, 1982; 2004a; 2004b; Brinkman-Van der Linden et al., 2002; Byrne et al., 2007; Lindberg, 2007; Bondioli et al., 2010). Due to their cell surface location these acidic molecules shield macromolecules and cells from enzymatic and immunological attacks and thus contribute to innate immunity (Schauer, 2004a; Hartlieb et al., 2008; Hidari et al., 2009). The cell surface location of sialic acids allows them to mask epitopes on the underlying glycan chains by repulsing negatively charged moieties (Byrne et al., 2007). Neu5Ac effectively blocks important antigenic sites and recognition markers on the cell surfaces, protecting them from the identification and degradation by the surrounding immune system (Bondioli et al., 2010). In contrast to this masking role, sialic acids also act as recognition sites for various physiological receptors, such as selectins and singlecs, as well as for toxins, viruses and bacteria, and thus allow colonization of cells (Schauer, 2004b; Byrne et al., 2007; Inayat-ur-Rahman et al., 2009; Wang, 2009).

The sialylation of glycoproteins and glycolipids plays an important role during the development and regeneration, and also in the pathogenesis of several diseases. The sialylated Neuronal Cell Adhesion Molecule (NCAM) is expressed on several neuroendocrine tumors of high malignancy and correlates with poor prognosis (Rutishauser, 1998; Horstkorte et al., 2004; Murphy et al., 2009). As an oncodevelopmental antigen sialic acid is reexpressed during the progression of numerous malignant human tumors, including small cell lung carcinoma, Wilms's tumor, neuroblastoma, and rhabdomyosarcoma. In these tumors, the sialylation of NCAM appears to increase the metastatic potential and has been correlated with the tumor progression (Seidenfaden et al., 2003; Bonfanti, 2006; Pentak et al., 2008; Tan et al., 2009).

Since sialic acids are involved in a wealth of biological phenomena, a change in their concentration or their chemical structure may alter the biology of cells (Schauer, 2004a). Studies with sialic acid-containing substances are required to understand these biological functions of sialic acid at the molecular level.

Biological membranes are complex systems which have attracted scientific interest for a long time and for various reasons. The mammalian cytoplasmic membranes contain mainly phosphatidylcholine, sphingomyelin, phosphatidylserine, phosphatidylethanolamine and cholesterol (Pozo Novas et al., 2005; Bonechi et al., 2009).

\footnotetext{
$\triangle$ e-mail: A.Timoszyk@wnb.uz.zgora.pl
}

Abbreviations: COSY, Correlation SpectroscopY; HETCOR, HETeronuclear CORrelation; Neu5Ac, N-acetylneuraminic acid; NCAM, neuronal cell adhesion molecule; Noise Band Decoupling (NBD) NOESY, Nuclear Overhauser Enhancement SpectroscopY; ROESY, Rotating-frame Overhauser Effect SpectroscopY; TOCSY, TOtally Correlated SpectroscopY. 
The hydrophobic/hydrophilic versatility and biocompatibility of the lipid molecules that readily form closed lipid bilayers with an aqueous interior have made these materials one of the most studied systems (Leal et al., 2008). Liposomes, since their discovery, have been used as models to investigate the properties of biological membranes and associated processes such as molecular recognition, enzymatic catalysis, cell adhesion and membrane fusion (Berquand et al., 2004; Pentak et al., 2008; Leal et al., 2008, Janiak-Osajca \& Timoszyk, 2012). Liposomes form via noncovalent self-assembly rendering them relatively easy to tailor in order to meet certain physicochemical properties like charge density, membrane fluidity, size and others (Pozo Novas et al., 2005).

The sialic acid-liposome interactions at the molecular level depend on their hydro-lipophilic characteristics. Sialic acid can interact in scalar and/or dipolar way with the polar headgroup or even with the hydrophobic hydrocarbon chains of phospholipids. Specific changes in the liposome morphology or the sialic acid conformation can also occur. The main aim of the present study was to investigate the changes of conformation and the type of interactions induced by sialic acid (2,8-( $N$-acetylneuraminic acid)) molecules on membrane-like systems, i.e., phosphatidylcholine (1,2-Diacyl-sn-glycero-3-phosphocholine) liposomes by 2D NMR (TOCSY, HETCOR, ROESY). The model bilayers were studied, in the absence and presence of sialic acid.

\section{MATERIALS AND METHODS}

Egg yolk phosphatidylcholine (1,2-Diacyl-sn-glycero3-phosphocholine, purity $>99 \%$ ) (PC) was purchased from Sigma Aldrich, as lyophilized powder. Heavy water $\mathrm{D}_{2} \mathrm{O}$ (purity $=98.8 \%$ ) was purchased from ARMAR Chemicals, Łódź, Poland. Sialic acid (Colominic acid sodium salt) (2,8-(N-acetylneuraminic acid)) (SA) (purity $\geq$ 95\%) from Escherichia coli was obtained from Sigma Aldrich. The structure and numbering of the SA carbons is shown in Fig. 1. Colominic acid was isolated originally from Escherichia coli K235 by Barry \& Goebel (1957). It was shown to be macromolecular substance which give direct Ehrlich reaction indicating the presence of sialic acid. Colominic acid is a homopolymer of $N$-acetylneuraminic acid having 2-8 ketosialic linkages between the polymer units. C1 carboxyl group is esterified and is easily saponified with $\mathrm{NaOH}$. Substituent at C5 of $N$ acetylneuraminic is acetyl group (Ac) (McGuire \& Bincley, 1964).

Sample preparation and characterization. Unilamellar liposomes were prepared in the following manner. Appropriate amounts of PC were dissolved in $\mathrm{CHCl}_{3}$, mixed, and dried with nitrogen stream and kept under vacuum for $45 \mathrm{~min}$ to remove traces of the organic solvent. The dried thin film was then dispersed in $\mathrm{D}_{2} \mathrm{O}$

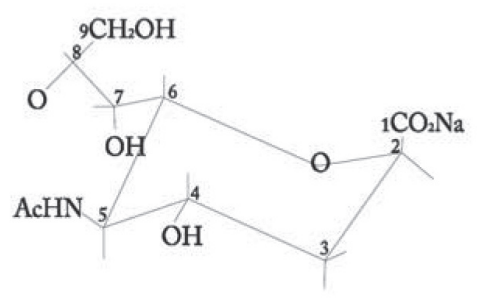

Figure 1. The structure of the SA (2,8-( $N$-acetylneuraminic acid $))$. Substituent at the carbon atom $\mathrm{C} 5$ is acetyl group $(\mathrm{Ac})\left(\mathrm{COCH}_{3}\right)$.
(25 mg of PC to $1 \mathrm{ml} \mathrm{D}_{2} \mathrm{O}$ ). Multilamellar vesicles were first obtained upon vortexing. Subsequent ultrasonication using a $20 \mathrm{kHz}$ sonicator with a titanium probe, for 30 min produced unilamellar liposomes. Earlier studies on phospholipid liposomes confirm that the sonication method allows one to obtain small unilamellar liposomes Jeżowska et al., 1994; Gabrielska \& Gruszecki, 1996; Kuczera et al., 1997; Wenk \& Seeling, 1998; Timoszyk \& Janas, 2003; Timoszyk et al., 2004). Sialic acid was added to the liposome suspension, the constant concentration $20 \mathrm{mg} / \mathrm{ml} \mathrm{D}_{2} \mathrm{O}$, and the mixture was vortexed.

2D NMR techniques. 2D NMR experiments deliver information about a molecule's structure and they are the method of choice to study membrane-sugar interactions (Potrzebowski et al., 2001; Latanowicz et al., 2011). In a Correlation SpectroscopY (COSY) experiment, magnetization (sum of all of nuclear magnetic moments in a sample along the field direction) is transferred by scalar coupling. Two-dimensional COSY experiments allow one to determine the connectivity of a molecule by determining which protons are spin-spin coupled. A COSY experiment gives information regarding three-bond couplings (from a proton to its carbon, to the adjacent

\section{A. COSY experiment}
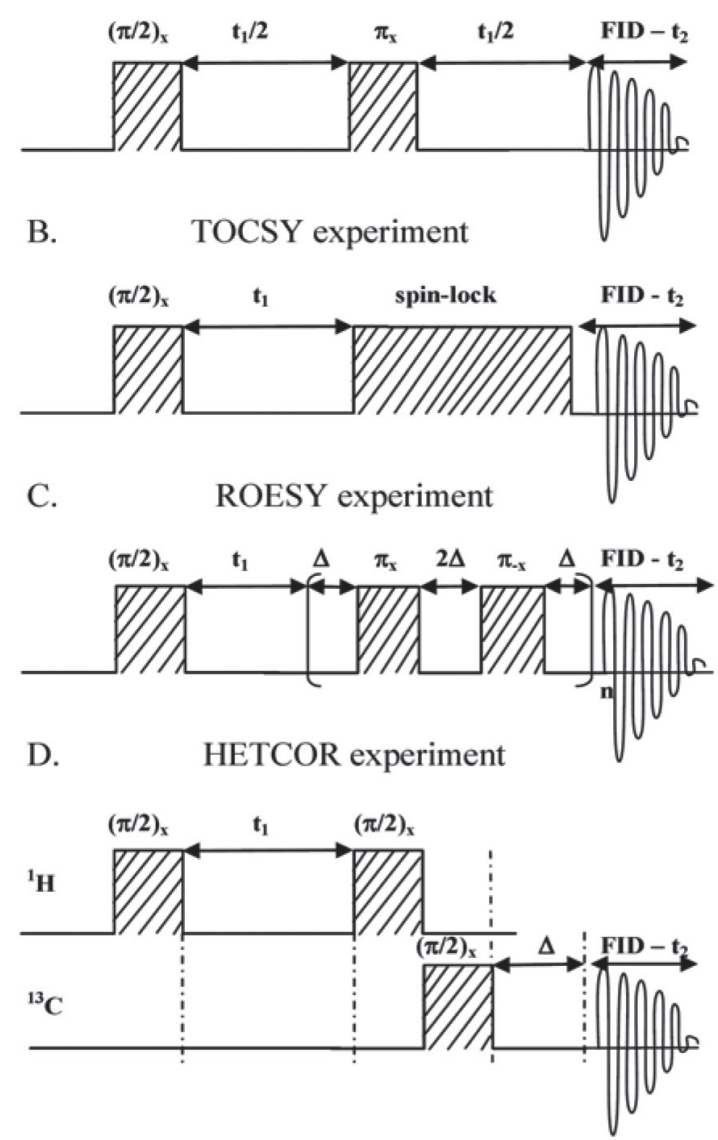

Figure 2. Two dimensional NMR pulse sequences.

(A) ${ }^{1} \mathrm{H}^{1} \mathrm{H}$ COSY experiment: $t_{1}$ - time between pulses, $t_{2}-$ acquisition time, $(\pi / 2)_{x}$ - pulse angle. (B) ${ }^{1} \mathrm{H}^{1} \mathrm{H}$ TOCSY experiment: $(\pi / 2)_{x}$ and $\pi_{x}$ - pulse angle, $t_{1}$ - time between pulses, spin-lock - during the mixing phase (mixing of spin states) following the pulse a 'spin-lock' condition is applied, and polarization is transferred from selected protons, $t_{2}-$ acquisition time. (C) ${ }^{1} \mathrm{H}^{\mathrm{H}} \mathrm{H}$ ROESY experiment: $t_{1}$ - time between pulses, $\Delta-$ internal fixed time, $(\pi / 2)_{x} \pi_{x}$ and $\pi_{-x}-$ pulse angle, $t_{2}-$ acquisition time. (D) ${ }^{1} \mathrm{H}^{13} \mathrm{C}$ HETCOR experiment: $(\pi / 2)_{x}-$ pulse angle, $t_{1}-$ time between pulses, $\Delta-$ internal fixed time, $t_{2}-$ acquisition time. 
carbon, then to that carbon's proton) (Lindman et al., 1995). More extensive COSY spectra may be generated by advanced techniques, allowing one to view four-, five-, and occasionally six-bond couplings. The pulse sequence for a homonuclear proton COSY experiment is the following: ${ }^{1} \mathrm{H}-(\pi / 2)_{x}-t_{1} / 2-(\pi)_{x}-t_{1} / 2$-FID $-t_{2}$, where $(\pi / 2)_{x}$ and $(\pi) t_{x}$ are pulse angles, $t_{1}$ is the time between pulses, $t_{2}$ is the acquisition time and FID is the Free Indication Decay (Fig. 2A) (Lindman et al., 1995).

The magnetization is dispersed over a complete spin system of a molecule by successive scalar coupling in a TOtally Correlated SpectroscopY (TOCSY) experiment. Cross-peaks, both the COSY-type and the TOCSY-type, can be observed due to the coherence transfer between the scalar coupled spins (Friebolin, 1990; Kadkhodaei et al., 1991).

A TOCSY experiment correlates all protons of a spin system. Therefore, TOCSY spectra show not only the signals appearing in the COSY spectrum, but also the additional signals which originate from the interaction of all the protons of the spin system that are not directly connected via three chemical bonds. The pulse sequence for a TOCSY experiment is the following: ${ }^{1} \mathrm{H}$ $(\pi / 2)_{x}-t_{1}$ - spin-lock pulse-FID- $t_{2}$, where spin-lock means that a radio-frequency field is applied along the $y$ axis for a time $t_{1}$. This field 'locks' the nuclear magnetization which has been flipped to the $y$ axis by the initial $(\pi / 2)$ $\pi_{x}$ pulse, avoiding any precession due to $B$ inhomogeneity (Fig. 2B) (Friebolin, 1990; Canet \& Robert, 1995). One of the most popular mixing schemes (spin-lock) in TOCSY is MLEV-17. During this pulse sequence, after the evolution period $t_{1}$, magnetization is spin-locked (for example by a series of $180^{\circ}$ pulses). During this mixing time the magnetization is exchanged through scalar coupling (Friebolin, 1990; Schleucher et al., 1996). During this spin-lock period, the magnetization behaves as a strong coupled spin system and evolves under the influence of a 'collective spin-mode'. In that collective mode, the coherence transfer is possible between all coupled nuclei in the spin system (even if they are not directly coupled) (Friebolin, 1990).

A Nuclear Overhauser Enhancement SpectroscopY (NOESY) experiment correlates all protons which are close enough. The intensity of the NOE in the first approximation is proportional to $1 / r^{6}$, where $r$ is the distance between the protons (Friebolin, 1990). The correlation between two protons depends on the distance between them, but normally a signal is observed if their distance is smaller than $5 \AA$ (Schleucher et al., 1996). The Rotating-frame Overhauser Effect SpectroscopY (ROESY) is a homonuclear experiment, similar to the NOESY experiment, in which homonuclear NOE effects are measured under spin-locked conditions. ROESY is especially suited for molecules with motional correlation times $(\tau)$ such that $\omega \tau_{c} \sim 1$, where $\omega$ is the angular frequency $\omega=\gamma B$. In such cases the NOE is nearly zero, but the rotating-frame ROE is always positive and increases monotonically for increasing values of $\tau_{c}$ (Friebolin, 1990; Schleucher et al., 1996). In ROESY a mixing time is the spin-lock period. During this time the spin exchange occurs among the spin-locked magnetization components of different nuclei (recall that spin exchange in NOESY occurs while the magnetization is aligned along the $z$ axis) (Bax \& Grzesiek, 1996). Different spectral density functions are relevant to ROESY than to NOESY and these cause ROE to be positive for all values of $\tau_{i}$. The ROESY pulse sequence is the following: ${ }^{1} \mathrm{H}-(\pi / 2)_{x}-t_{1}-\left(\Delta-\pi_{x}-2 \Delta-\pi_{-x}-\Delta\right)_{n}-\mathrm{FID}-t_{2}$, where $\Delta$ is the internal fixed time (Fig. 2C) (Friebolin, 1990).
Table 1. Assignments of ${ }^{1} \mathrm{H}-{ }^{13} \mathrm{C}$ couplings from the HETCOR spectrum of SA.

\begin{tabular}{llll}
\hline HETCOR & f1 [ppm] & f2[ppm] \\
\hline 1 & $\mathrm{NHCO}(\mathrm{C} 1 / \mathrm{H} 1)_{3}$ & 21.9057 & 2.009 \\
\hline 2 & $\mathrm{C} 3 / \mathrm{H} 3 \mathrm{a}$ & 38.7220 & 1.668 \\
\hline 3 & $\mathrm{C} 3 / \mathrm{H} 3 \mathrm{C}$ & 38.7220 & 2.598 \\
\hline 4 & $\mathrm{C} 5 / \mathrm{H} 5$ & 51.5992 & 3.737 \\
\hline 5 & $\mathrm{C} 9 / \mathrm{H} 9$ & 60.5477 & 3.575 \\
\hline 6 & $\mathrm{C} 9 / \mathrm{H} 9^{\prime}$ & 60.5477 & 4.129 \\
\hline 7 & $\mathrm{C} 4 / \mathrm{H} 4$ & 68.6280 & 3.511 \\
\hdashline 8 & $\mathrm{C} 7 / \mathrm{H} 7$ & 68.6280 & 3.821 \\
\hdashline 9 & $\mathrm{C} 6 / \mathrm{H} 6$ & 72.1624 & 3.540 \\
\hline 10 & $\mathrm{C} 8 / \mathrm{H} 8$ & 77.2702 & 4.027 \\
\hline
\end{tabular}

A two dimensional $\mathrm{H}, \mathrm{C}$ correlation experiment, HETeronuclear CORrelation (HETCOR), yields cross signals for all protons and ${ }^{13} \mathrm{C}$ nuclei which are connected by a ${ }^{13} \mathrm{C},{ }^{1} \mathrm{H}$ coupling over one bond (Lindman et al., 1995). The two nuclei observed most often are ${ }^{13} \mathrm{C}$ and ${ }^{1} \mathrm{H}$, but this technique can be applied to other spin $1 / 2$ nuclei, for instance ${ }^{31} \mathrm{P}$ and ${ }^{19} \mathrm{~F}$. The pulse sequence for the HETCOR experiment is as follows: ${ }^{1} \mathrm{H}-(\pi / 2)_{x}-t_{1}-$ $(\pi / 2)_{x}-t_{1}$ (decoupling on) ${ }^{13} \mathrm{C}-(\pi / 2)_{x}-\Delta$-FID- $t_{2}$ (Fig. 2D) (Friebolin, 1990). A two dimensional ${ }^{1} \mathrm{H}^{13} \mathrm{C}$ correlation experiment yields cross-peaks for all protons and ${ }^{13} \mathrm{C}$ nuclei which are connected by the ${ }^{1} \mathrm{H}^{13} \mathrm{C}$ coupling over one bond (Kadkhodaei et al., 1991). The ${ }^{1} \mathrm{H}^{13} \mathrm{C}$ correlation is of great use for structure determinations using NMR along with ${ }^{1} \mathrm{H}^{1} \mathrm{H}$ COSY.

NMR experiment. All spectra were recorded on a BRUKER DRX-500 NMR spectrometer working at the ${ }^{1} \mathrm{H}$ frequency of $500.133 \mathrm{MHz}$ and collected at a nominal probe temperature $300 \mathrm{~K}( \pm 0.01 \mathrm{~K})$, using the standard pulse sequence: the introduction of the spin echo sequence in ROESY experiments; and HSQC (Heteronuclear Single Quantum Coherence) sequence with pulsed field gradients to suppress artifacts in HETCOR experiment. The pulse sequence consisted of a pulse of the average duration of $10.5 \mu \mathrm{s}\left(90^{\circ}\right)$ and repetition time $5 \mathrm{~s}$, and relaxation time $370 \mathrm{~ms}$.

\section{RESULTS}

Figure $3 \mathrm{~A}$ shows full assignments for the proton resonances from an ${ }^{1} \mathrm{H}$ NMR spectrum of SA. The spectrum reveals a relatively numerous resonance lines, especially in the range (3.5-4.2) ppm, although not all the resonance lines are sufficiently separated (Fig. 3A).

A series of $2 \mathrm{D}$ experiments were undertaken to assign those lines: ${ }^{1} \mathrm{H}^{13} \mathrm{C}$ HETCOR (Fig. 4, Table 1), ${ }^{1} \mathrm{H}^{1} \mathrm{H}$ COSY and the ${ }^{1} \mathrm{H}^{1} \mathrm{H}$ TOCSY (spectra not shown) (Table 2.).

2D NMR measurements are time consuming and require specific conditions. The measurements of the studied sample were performed at $27^{\circ} \mathrm{C}(300 \mathrm{~K})$, at which temperature SA in distilled water are stable for a few days (Yamasaki \& Bacon, 1991).

The $2 \mathrm{D}$ spectrum of ${ }^{1} \mathrm{H}^{13} \mathrm{C}$ NMR (HETCOR) permitted a correlated analysis of the data provided by the 1D proton and 1D carbon spectra (Fig. 4, Table 1.), which allowed the assignment of protons to a given carbon atom (Fig. 1). 


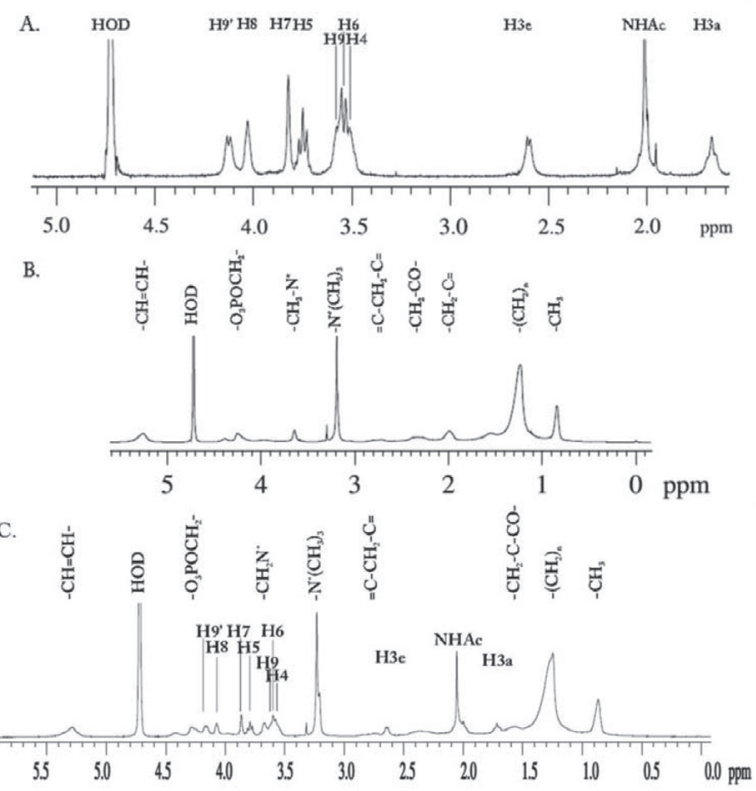

Figure 3. Assignments of proton resonances from ${ }^{1} H$ NMR spectra of:

(A) SA; (B) PC liposomes; (C) PC liposomes in the presence of SA.

Owing to the Noise Band Decoupling (NBD) method application (broadband decoupling of ${ }^{1} \mathrm{H}-{ }^{13} \mathrm{C}$ interactions) the ${ }^{13} \mathrm{C}$ NMR spectrum revealed carbon signals in the form of singlets instead of multiplets.

The presence of the H4, H6, H9 and H9' protons was confirmed by the heteronuclear 2D experiment, and their proton chemical shift were found (Table 1). The correlation spectrum ${ }^{1} \mathrm{H}^{13} \mathrm{C}$ HETCOR permits the distinction of signals assigned to protons H4 and H6 (Fig. 4), whose signals in the ${ }^{1} \mathrm{H}$ spectrum were undistinguishable (Fig. 3A). The intensity of signals assigned to carbons C3 and C9 lower than that of the signals assigned to C6, $\mathrm{C} 8$ and $\mathrm{C} 5$ can be explained by longer relaxation times of the former. Protons $\mathrm{H} 8, \mathrm{H} 5$ are bound to carbons $\mathrm{C} 8, \mathrm{C} 5$ and the carbon from the Ac group. The ${ }^{1} \mathrm{H}^{13} \mathrm{C}$ HETCOR spectrum shows the coross-peaks between carbons $\mathrm{C} 7$ and $\mathrm{C} 4$ (these signals are indiscernible) and protons $\mathrm{H} 4$ and $\mathrm{H} 7$ (Fig. 4, Table 1). Protons H3a and

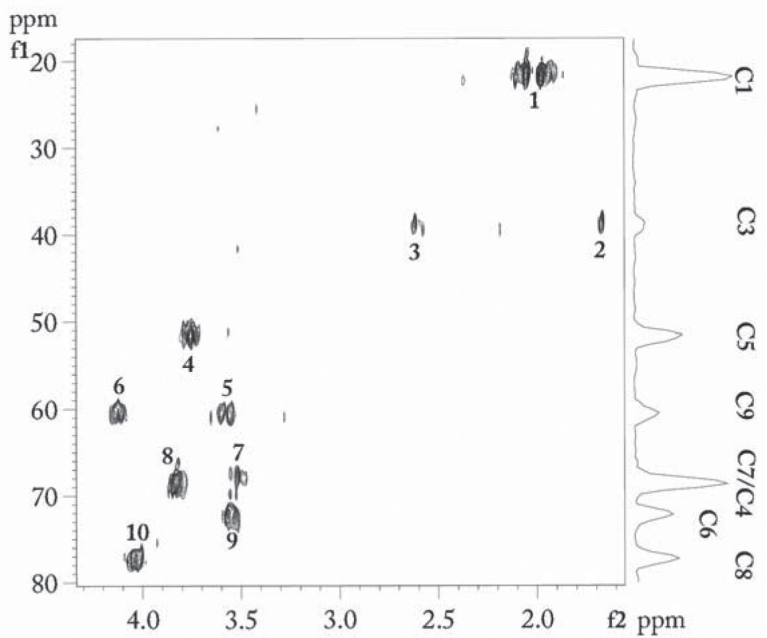

Figure 4. ${ }^{1} \mathrm{H}^{13} \mathrm{C}$ HETCOR spectrum of SA.
Table 2. Assignments of proton characteristic resonances from ${ }^{1} \mathrm{H}^{1} \mathrm{H}$ TOCSY spectrum of SA.

\begin{tabular}{llll}
\hline \multicolumn{2}{l}{ TOCSY } & f1 [ppm] & f2 [ppm] \\
\hline 1 & H3e/H3a & 2.598 & 1.668 \\
\hline 2 & H4/H3a & 3.511 & 1.668 \\
\hline 3 & H6/H3a & 3.540 & 1.668 \\
\hline 4 & H9/H3a & 3.575 & 1.668 \\
\hline 5 & H5/H3a & 3.747 & 1.668 \\
\hline 6 & H4/H3e & 3.511 & 2.598 \\
\hline 7 & H6/H3e & 3.540 & 2.598 \\
\hline 8 & H9/H3e & 3.575 & 2.598 \\
\hline 9 & H5/H3e & 3.747 & 2.598 \\
\hline 10 & H5/H6 & 3.747 & 3.540 \\
\hline 11 & H7/H4 & 3.821 & 3.511 \\
\hline 12 & H9/H6 & 3.575 & 3.540 \\
\hline 13 & H8/H6 & 4.027 & 3.540 \\
\hline 14 & H9'/H6 & 4.129 & 3.540 \\
\hline 15 & H8/H7 & 4.027 & 3.821 \\
\hline 16 & H9'/H7 & 4.129 & 3.821 \\
\hline 17 & H9'/H8 & 4.129 & 4.027 \\
\hline & & & \\
\hline
\end{tabular}

$\mathrm{H} 3 \mathrm{e}$ give correlation signals with carbon C3. The hydrogen atom whose bond is parallel (axial) to the vertical symmetry axis of the ring is denoted as $\mathrm{H} 3 \mathrm{a}$, while that whose bond is perpendicular to this axis (equatorial) and lies in the plane of the ring is denoted as H3e. Carbons $\mathrm{C} 1$ and $\mathrm{C} 2$ do not give coross-peaks as they are not directly bound to a hydrogen atom: C1 comes from the carboxyl group and C2 is attached to the hydroxyl group (Fig. 4).

The ${ }^{1} \mathrm{H}^{1} \mathrm{H}$ TOCSY spectrum permitted the observation of all the scalar couplings even over distances greater than two chemical bonds. TOCSY is a useful technique to determine bond connectivities and a complete assignment of the ${ }^{1} \mathrm{H}$ spectrum was only possible by us-

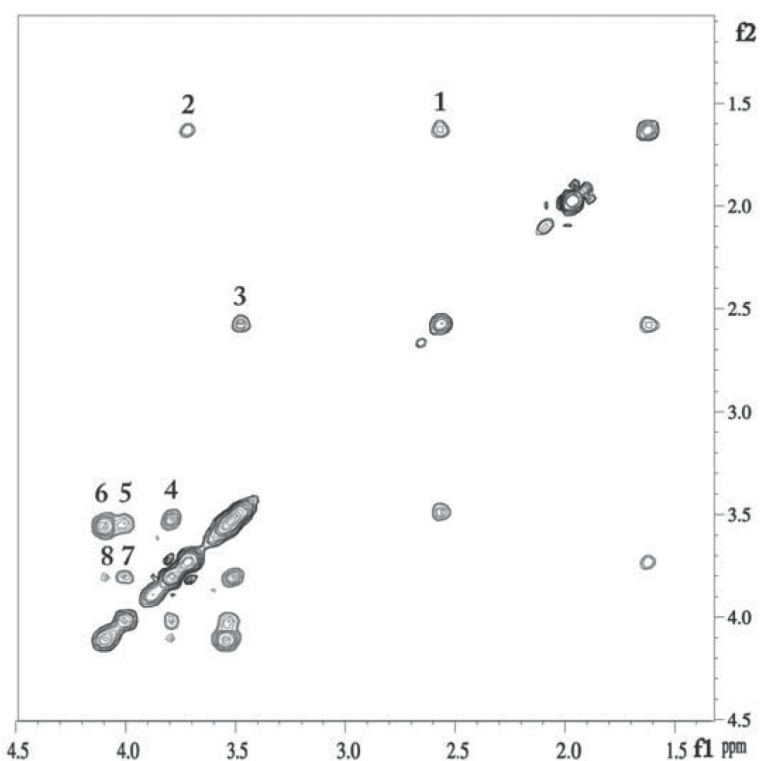

Figure 5. ${ }^{1} \mathrm{H}^{1} \mathrm{H}$ ROESY spectrum of $\mathrm{SA}$. 
Table 3. Assignments of proton characteristic resonances from ${ }^{1} \mathrm{H}^{1} \mathrm{H}$ ROESY spectrum of SA.

\begin{tabular}{|c|c|c|c|}
\hline \multicolumn{2}{|c|}{ ROESY } & \multirow{2}{*}{$\frac{\mathrm{f} 1 \text { [ppm] }}{2.598}$} & \multirow{2}{*}{$\begin{array}{l}\mathrm{f} 2[\mathrm{ppm}] \\
1.668\end{array}$} \\
\hline 1 & $\mathrm{H} 3 \mathrm{e} / \mathrm{H} 3 \mathrm{a}$ & & \\
\hline 2 & H5/H3a & 3.598 & 1.668 \\
\hline 3 & $\mathrm{H} 4 / \mathrm{H} 3 \mathrm{e}$ & 3.511 & 2.598 \\
\hline 4 & $\mathrm{H} 7 / \mathrm{H} 4$ & 3.821 & 3.511 \\
\hline 5 & $\mathrm{H} 8 / \mathrm{H} 6$ & 4.027 & 3.540 \\
\hline 6 & $\mathrm{H} 9^{\prime} / \mathrm{H} 6$ & 4.129 & 3.540 \\
\hline 7 & $\mathrm{H} 8 / \mathrm{H} 7$ & 4.027 & 3.821 \\
\hline 8 & $\mathrm{H} 9^{\prime} / \mathrm{H} 7$ & 4.129 & 3.821 \\
\hline
\end{tabular}

ing 2D homo- and heteronuclear experiments, because of the overlapping sets of protons (Figure 3A.). Seventeen correlation signals were determined in the ${ }^{1} \mathrm{H}^{1} \mathrm{H}$ TOCSY spectrum of SA (Table 2.).

Figure 5 shows an ${ }^{1} \mathrm{H}^{1} \mathrm{H}$ ROESY spectrum of SA. The cross signals from the ${ }^{1} \mathrm{H}^{1} \mathrm{H}$ ROESY spectrum have been assigned. The assignments of the dipole-dipole couplings are shown in Table 3. As follows from the ${ }^{1} \mathrm{H}^{1} \mathrm{H}$ ROESY spectrum, all the neighbouring hydrogen nuclei are engaged in the dipole interactions.

The signals recorded correspond to the dipole-dipole couplings between the following pairs of hydrogens: $\mathrm{H3e}$ and $\mathrm{H} 3 \mathrm{a}$ (at $\mathrm{C} 3$ ), $\mathrm{H} 3 \mathrm{e}$ and $\mathrm{H} 4$ (at $\mathrm{C} 3$ and $\mathrm{C} 4$ ), $\mathrm{H} 3 \mathrm{a}$ and $\mathrm{H} 5$ (at $\mathrm{C} 3$ and $\mathrm{C} 5$ ), $\mathrm{H} 7$ and $\mathrm{H} 4$ (at $\mathrm{C} 7$ and $\mathrm{C} 4), \mathrm{H} 8$ and H6 (at C8 and C6), $\mathrm{H} 8$ and $\mathrm{H} 7$ (at $\mathrm{C} 8$ and $\mathrm{C} 7$ ), H9' and $\mathrm{H} 6$ (at $\mathrm{C} 9$ and $\mathrm{C} 6$ ) and $\mathrm{H} 9$ ' and $\mathrm{H} 7$ (at $\mathrm{C} 9$ and $\mathrm{C} 7$ ) (Table 3). One of the interacting protons is also engaged in scalar coupling $(\mathrm{H} 3 \mathrm{e}$ and $\mathrm{H} 4)$. The other interactions between the protons at $\mathrm{C} 3$ and $\mathrm{C} 5, \mathrm{C} 7$ and $\mathrm{C} 4, \mathrm{C} 8$ and C6, C9 and C6, and C9' and $\mathrm{C} 7$ are only dipolar ( $\mathrm{Ta}-$ ble 3).

Figure 3B shows full assignments for the proton resonances from the ${ }^{1} \mathrm{H}$ NMR spectrum of the unilamellar PC liposomes. An analysis of the TOCSY spectrum of the PC liposomes (spectrum not shown) helped to describe the ${ }^{1} \mathrm{H}$ NMR spectrum (Table 4). It was possible to identify all the proton resonances belonging to the same spin system due to the selective excitation of each proton in the molecule in the TOCSY experiment. The correlation signals in the ${ }^{1} \mathrm{H}^{1} \mathrm{H}$ TOCSY spectrum of the PC liposomes showing scalar coupling of protons by more than two chemical bonds are: $-\mathrm{CH}_{3} /-\left(\mathrm{CH}_{2}\right)_{\mathrm{n}}$, $-\mathrm{CH}_{3} /-\mathrm{CH}_{2}-\mathrm{C}=,-\left(\mathrm{CH}_{2}\right)_{\mathrm{n}} /-\mathrm{CH}_{2}-\mathrm{C}=,-\left(\mathrm{CH}_{2}\right)_{\mathrm{n}} /-\mathrm{CH}=\mathrm{CH}-$, $-\mathrm{CH}_{2}-\mathrm{C}=/=\mathrm{C}-\mathrm{CH}_{2}-\mathrm{C}=, \quad-\mathrm{CH}_{2}-\mathrm{C}=/-\mathrm{CH}=\mathrm{CH}-$, $-\mathrm{CH}=\mathrm{CH}-/=\mathrm{C}-\mathrm{CH}_{2}-\mathrm{C}=$ and $-\mathrm{CH}_{2}-\mathrm{N}^{+} /-\mathrm{O}_{3} \mathrm{POCH}_{2}(\mathrm{Ta}-$ ble 4).

Table 4. Assignments of proton characteristic resonances from ${ }^{1} \mathrm{H}^{1} \mathrm{H}$ TOCSY spectrum of PC liposomes.

\begin{tabular}{cccc}
\hline \multicolumn{2}{l}{ TOCSY } & f1 [ppm] & f2 [ppm] \\
\hline 1 & $-\left(\mathrm{CH}_{2}\right)_{\mathrm{n}} /-\mathrm{CH}_{3}$ & 1.131 & 0.748 \\
\hdashline 2 & $-\mathrm{CH}_{2}-\mathrm{C}=/-\mathrm{CH}_{3}$ & 1.903 & 0.748 \\
\hline 3 & $-\left(\mathrm{CH}_{2}\right)_{\mathrm{n}} /-\mathrm{CH}_{2}-\mathrm{C}=$ & 1.131 & 1.903 \\
\hdashline 4 & $-\left(\mathrm{CH}_{2}\right)_{\mathrm{n}} /-\mathrm{CH}=\mathrm{CH}-$ & 1.131 & 5.178 \\
\hdashline 5 & $=\mathrm{C}-\mathrm{CH}_{2}-\mathrm{C}=/-\mathrm{CH}_{2}-\mathrm{C}=$ & 2.643 & 1.903 \\
\hdashline 6 & $-\mathrm{CH}=\mathrm{CH}-/-\mathrm{CH}_{2}-\mathrm{C}=$ & 5.178 & 1.903 \\
\hdashline 7 & $=\mathrm{C}-\mathrm{CH}_{2}-\mathrm{C}=/-\mathrm{CH}_{2} \mathrm{CH}-$ & 2.643 & 5.178 \\
\hdashline 8 & $-\mathrm{CH}_{2}-\mathrm{N}+/-\mathrm{O}_{3} \mathrm{POCH}_{2}-$ & 3.561 & 4.171 \\
\hline
\end{tabular}

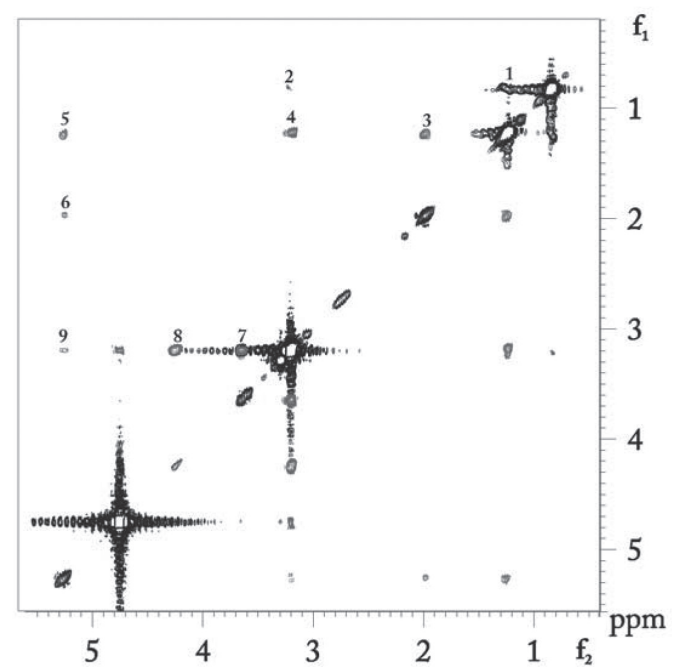

Figure 6. ${ }^{1} \mathrm{H}^{1} \mathrm{H}$ ROESY spectrum of PC liposomes.

Table 5. Assignments of proton characteristic resonances from ${ }^{1} \mathrm{H}^{1} \mathrm{H}$ ROESY spectrum of PC liposomes.

\begin{tabular}{cccc}
\hline ROESY & f1 [ppm] & f2 [ppm] \\
\hline 1 & $-\mathrm{CH}_{3} /-\left(\mathrm{CH}_{2}\right)_{\mathrm{n}}$ & 0.748 & 1.131 \\
\hdashline 2 & $-\mathrm{CH}_{3} /-\mathrm{N}^{+}\left(\mathrm{CH}_{3}\right)_{3}$ & 0.748 & 3.119 \\
\hdashline 3 & $-\left(\mathrm{CH}_{2}\right)_{\mathrm{n}} /-\mathrm{CH}_{2}-\mathrm{C}=$ & 1.131 & 1.903 \\
\hdashline 4 & $-\left(\mathrm{CH}_{2}\right)_{\mathrm{n}} /-\mathrm{N}+\left(\mathrm{CH}_{3}\right)_{3}$ & 1.131 & 3.119 \\
\hdashline 5 & $-\left(\mathrm{CH}_{2}\right)_{\mathrm{n}} /-\mathrm{CH}=\mathrm{CH}-$ & 1.131 & 5.178 \\
\hline 6 & $-\mathrm{CH}_{2}-\mathrm{C}=/-\mathrm{CH}=\mathrm{CH}-$ & 1.903 & 5.178 \\
\hdashline 7 & $-\mathrm{N}^{+}\left(\mathrm{CH}_{3}\right)_{3} /-\mathrm{CH}_{2}-\mathrm{N}^{+}$ & 3.119 & 3.561 \\
\hdashline 8 & $-\mathrm{N}^{+}\left(\mathrm{CH}_{3}\right)_{3} /-\mathrm{O}_{3} \mathrm{POCCH}-$ & 3.119 & 4.171 \\
\hdashline 9 & $-\mathrm{N}+\left(\mathrm{CH}_{3}\right)_{3} /-\mathrm{CH}_{2} \mathrm{CH}^{-}$ & 3.119 & 5.178 \\
\hline
\end{tabular}

Figure 6 shows an ${ }^{1} \mathrm{H}^{1} \mathrm{H}$ ROESY spectrum of the PC liposomes. The cross signals from the ${ }^{1} \mathrm{H}^{1} \mathrm{H}$ ROESY spectrum indicate dipole interactions, which have been assigned (Table 5).

The cross-peaks recorded in the ${ }^{1} \mathrm{H}^{1} \mathrm{H}$ ROESY of the PC liposomes correspond to dipole-dipole couplings: $-\mathrm{CH}_{3} /-\left(\mathrm{CH}_{2}\right)_{\mathrm{n}}, \quad-\left(\mathrm{CH}_{2}\right)_{\mathrm{n}} /-\mathrm{CH}_{2}-\mathrm{C}=, \quad-\mathrm{N}^{+}\left(\mathrm{CH}_{3}\right)_{3} /-\mathrm{CH}_{3}$, $-\mathrm{N}^{+}\left(\mathrm{CH}_{3}\right)_{3} /-\left(\mathrm{CH}_{2}\right)_{\mathrm{n}}, \quad-\left(\mathrm{CH}_{2}\right)_{\mathrm{n}} /-\mathrm{CH}=\mathrm{CH}-, \quad-\mathrm{CH}=\mathrm{CH}-/-$ $\mathrm{CH}_{2}-\mathrm{C}=,-\mathrm{N}^{+}\left(\mathrm{CH}_{3}\right)_{3} /-\mathrm{CH}_{2}-\mathrm{N}^{+},-\mathrm{N}^{+}\left(\mathrm{CH}_{3}\right)_{3} /-\mathrm{O}_{3} \mathrm{POCH}_{2}$ and ${ }^{-N^{+}}\left(\mathrm{CH}_{3}\right)_{3} /-\mathrm{CH}=\mathrm{CH}-$ (Fig. 6, Table 5). Almost all protons are also engaged in scalar couplings (Table 4). The ROESY spectrum of the PC liposomes showed some dipole-dipole couplings between the neighboring protons. Two signals corresponding to an interaction between the hydrophilic and hydrophobic parts of the liposome membrane were also recorded in the ROESY spectrum (Table 5).

Figure 3C shows full assignments for the proton resonances from the ${ }^{1} \mathrm{H}$ NMR spectrum of the PC liposomes in the presence of SA. Earlier studies of the ${ }^{1} \mathrm{H}^{1} \mathrm{H}$ TOCSY spectrum (spectrum not shown) of the PC liposomes in the presence of SA helped to describe the ${ }^{1} \mathrm{H}$ NMR spectrum (Fig. 3C). Scalar interactions between the PC and SA molecules have not been found in the ${ }^{1} \mathrm{H}^{1} \mathrm{H}$ TOCSY spectrum.

Figure 7 shows an ${ }^{1} \mathrm{H}^{1} \mathrm{H}$ ROESY spectrum of the PC liposomes in the presence of SA. The cross-peaks in the ${ }^{1} \mathrm{H}^{1} \mathrm{H}$ ROESY spectrum have been assigned (Table 6.). 
Table 6. Assignments of proton characteristic resonances from ${ }^{1} \mathrm{H}^{1} \mathrm{H}$ ROESY spectra of PC liposomes in the presence of SA.

\begin{tabular}{|c|c|c|c|}
\hline \multicolumn{2}{|c|}{ ROESY } & \multirow{2}{*}{$\begin{array}{l}\mathrm{f} 1 \text { [ppm] } \\
1.131\end{array}$} & \multirow{2}{*}{$\begin{array}{l}\text { f2 [ppm] } \\
0.748\end{array}$} \\
\hline 1 & $-\left(\mathrm{CH}_{2}\right)_{\mathrm{n}} /-\mathrm{CH}_{3}$ & & \\
\hline 2 & $-\mathrm{N}+\left(\mathrm{CH}_{3}\right)_{3} /-\mathrm{CH}_{3}$ & 3.119 & 0.748 \\
\hline 3 & $\mathrm{NHAC} /-\left(\mathrm{CH}_{2}\right)_{n}$ & 2.009 & 1.131 \\
\hline 4 & $-\mathrm{N}+\left(\mathrm{CH}_{3}\right)_{3} /-\left(\mathrm{CH}_{2}\right)_{\mathrm{n}}$ & 3.119 & 1.131 \\
\hline 5 & $\mathrm{H} 3 \mathrm{e} / \mathrm{H} 3 \mathrm{a}$ & 2.598 & 1.668 \\
\hline 6 & $\mathrm{H} 5 / \mathrm{H} 3 \mathrm{a}$ & 3.598 & 1.668 \\
\hline 7 & $\mathrm{H} 4 / \mathrm{H} 3 \mathrm{e}$ & 3.511 & 2.598 \\
\hline 8 & $-\mathrm{CH}_{2}-\mathrm{N}+/-\mathrm{N}+\left(\mathrm{CH}_{3}\right)_{3}$ & 3.561 & 3.119 \\
\hline 9 & $\mathrm{H} 7 / \mathrm{H} 4$ & 3.821 & 3.511 \\
\hline 10 & $\mathrm{H} 8 / \mathrm{H} 6$ & 4.027 & 3.540 \\
\hline 11 & $\mathrm{H} 9^{\prime} / \mathrm{H} 6$ & 4.129 & 3.540 \\
\hline
\end{tabular}

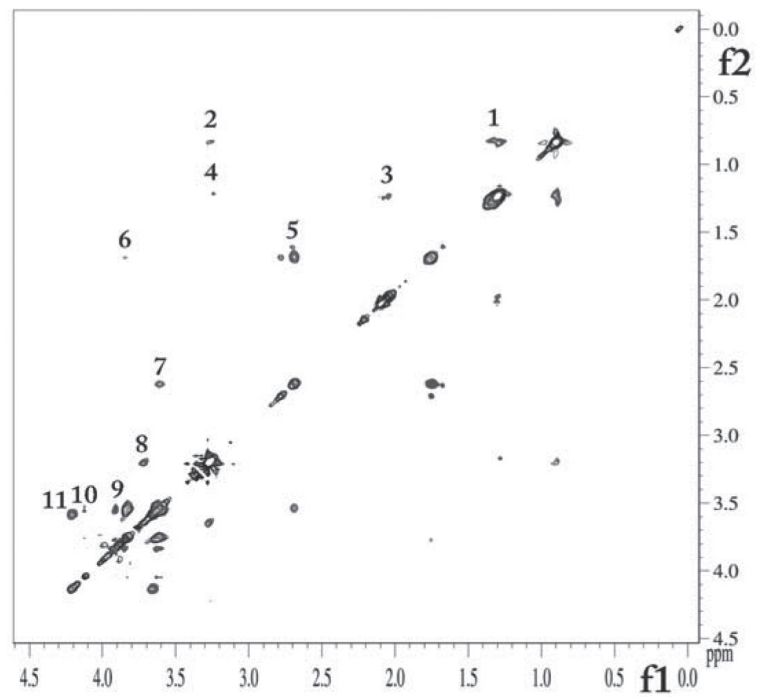

Figure 7. ${ }^{1} \mathrm{H}^{1} \mathrm{H}$ ROESY spectrum of PC liposomes in the presence of SA.

Eleven correlation signals representing dipole interactions were recorded (Fig. 7). Most of the observed signals reflect the effects already observed in the ROESY spectra of the PC liposomes (Fig. 6) and SA (Fig. 5) but some of them, i.e., $-\mathrm{N}^{+}\left(\mathrm{CH}_{3}\right)_{3} /-\mathrm{CH}=\mathrm{CH}-, \quad-\mathrm{CH}=\mathrm{CH}-$ $/-\mathrm{CH}_{2}-\mathrm{C}=, \quad-\mathrm{CH}=\mathrm{CH}-/-\left(\mathrm{CH}_{2}\right)_{\mathrm{n}}, \quad-\mathrm{CH}_{2}-\mathrm{C}=/-\left(\mathrm{CH}_{2}\right)_{\mathrm{n}}$, $-\mathrm{O}_{3} \mathrm{POCH}_{2} /-\mathrm{N}^{+}\left(\mathrm{CH}_{3}\right)_{3}$ and $\mathrm{H} 8 / \mathrm{H} 7, \mathrm{H} 9^{\prime} / \mathrm{H} 7$ could no longer be observed in the ROESY spectrum of the PC liposomes in the presence of SA (Fig. 7).

New dipole coupling between protons from the PC and SA molecules: NHCOCH$/-\left(\mathbf{C H}_{2}\right)_{n}$ was registered in the ${ }^{1} \mathrm{H}^{1} \mathrm{H}$ ROESY spectrum of the PC liposomes in the presence of SA (Table 6).

\section{DISCUSSION}

The proton signal assignment for SA (Fig. 3A) was based in ${ }^{1} \mathrm{H}^{1} \mathrm{H}$ COSY, ${ }^{1} \mathrm{H}^{1} \mathrm{H}$ TOCSY (Table 2$),{ }^{1} \mathrm{H}^{13} \mathrm{C}$ HETCOR (Fig. 4, Table 1) and ${ }^{1} \mathrm{H}^{1} \mathrm{H}$ ROESY (Fig. 5, Table 3) spectra and was in agreement with literature data (COSY and TOCSY spectra not shown) (Schauer, 1982; Yamasaki, 1988; Yamasaki \& Bacon, 1991; Brisson et al., 1992; Rutishauser, 1998; Brinkman-Van der Linden et al., 2002; Bonfati, 2006).

The ${ }^{1} \mathrm{H}$ spectrum of $\mathrm{PC}$ liposomes in $\mathrm{D}_{2} \mathrm{O}$ showed broad and unresolved signals, which did not allow the determination of the proton-proton scalar couplings (Fig. 3B). The poor resolution of resonances in this kind of systems is a typical characteristics of amphiphilic molecules that form aggregates (Bonechi et al., 2009). The reason of the drastic line broadening is the high concentration of protons in the lipids of the formed liposomes, and signal overlap (Bonechi et al., 2009). The reason to choose PC liposomes is that these phospholipids are the most common components of biological membranes. They are amphiphilic molecules in which a glycerol bridge links a pair of hydrophobic acyl hydrocarbon chains with the zwitterionic hydrophilic headgroup. Furthermore, small unilamellar liposomes obtained after sonication are well-hydrated membrane models. As previous studies showed, an increase in the curvature of liposomes caused an increase of the membrane hydration (Smith et al., 1996; Sabín et al., 2006; Shimanouchi et al., 2011). It has been reported that the rotational motion of the headgroup is related to hydrophobic interactions and hydrogen bonding or other interactions (Kaatze et al., 1985; Smith et al., 1996; Klösgen et al., 1996; Morita et al., 2003; Shimanouchi et al., 2011).

The presence of SA changes the dynamics of the membrane model. The use of high-resolution NMR methods such as ${ }^{1} \mathrm{H}^{1} \mathrm{H}$ COSY, ${ }^{1} \mathrm{H}^{1} \mathrm{H}$ TOCSY and ${ }^{1} \mathrm{H}^{1} \mathrm{H}$ ROESY (Fig. 7, Table 6) was necessary in order to determine the nature of the couplings between the interacting spins in such systems. The ${ }^{1} \mathrm{H}^{1} \mathrm{H}$ COSY and ${ }^{1} \mathrm{H}^{1} \mathrm{H}$ TOCSY spectra of the PC liposomes in the presence of SA have shown that the SA does not interact scalarly with the PC molecules. The supposed interaction between SA and the PC liposomes was investigated by ${ }^{1} \mathrm{H}^{1} \mathrm{H}$ ROESY spectra, with the aim of pointing out the differences in the dipole-dipole couplings that occur in aqueous solution (Fig. 5, Fig. 6 and Fig. 7). The nature of the interaction of SA with the model membrane depends on the structure of the phospholipid headgroup (Marcotte et al., 2004). The hydration of the polar headgroups of the PC molecules weakes $-\mathrm{O}_{3} \mathrm{POCH}_{2} /-\mathrm{N}^{+}\left(\mathrm{CH}_{3}\right)_{3}$ bond and that is why the reorientation of the headgroups of the phospholipids could break the intermolecular bonds (hydrogen and/or $-\mathrm{O}_{3} \mathrm{POCH}_{2} /-\mathrm{N}^{+}\left(\mathrm{CH}_{3}\right)_{3}$ bond) (Yamamoto et al., 1995; Pohle et al., 2004; Shimanouchi et al., 2011). The absence of dipole-dipole couplings within the choline head $\left(-\mathrm{O}_{3} \mathrm{POC} \mathbf{H}_{2} /-\mathrm{N}^{+}\left(\mathrm{CH}_{3}\right)_{3}\right)$, between the headgroups and glycerol $\left(-\mathrm{N}^{+}\left(\mathrm{CH}_{3}\right)_{3} /-\mathrm{CH}=\mathrm{CH}-\right)$, and between glycerol and fatty acid chains $(-\mathrm{CH}=\mathrm{CH}-$ $\left./-\mathrm{CH}_{2}-\mathrm{C}=, \quad=\mathrm{CH}=\mathrm{CH}-/-\left(\mathrm{CH}_{2}\right)_{\mathrm{n}}, \quad-\mathrm{CH}_{2}-\mathrm{C}=/-\left(\mathrm{CH}_{2}\right)_{\mathrm{n}}\right)$ indicates an increase of the membrane dynamics in the presence of SA (Fig. 7, Table 6). Moreover, the mobility of the glycerol backbone of the phospholipids, adjacent to the headgroup, is associated with the dynamics of the membrane interface (Walde \& Blochlinger, 1997). But a dipole interaction between the hydrophilic part (choline head) and the hydrophobic part (fatty acid chains) of the PC molecule $\left(\mathbf{N}^{+}\left(\mathrm{CH}_{3}\right)_{3} /-\mathrm{CH}_{3}, \mathrm{~N}^{+}\left(\mathrm{CH}_{3}\right)_{3} /-\left(\mathrm{CH}_{2}\right)_{\mathrm{n}}\right)$ can still be observed (Fig. 7). That intermolecular interaction can be characteristic to well hydrated membranes, when the high hydration of the headgroups will result in the exposure of the hydrophobic acyl chain of the liposome membrane (Shimanouchi et al., 2011).

The conformation of SA is changed in the presence of liposomes (Fig. 7). It depends, above all, on the stereochemistry of the chemical groups of the carbon atoms C7 and C8, and oxygen O8 (Yamasaki, 1988). The cross- 
peaks between the $\mathrm{H} 8 / \mathrm{H} 7$ and $\mathrm{H} 9$ ' $/ \mathrm{H} 7$ protons present in the ${ }^{1} \mathrm{H}^{1} \mathrm{H}$ ROESY spectrum of SA (Fig. 5, Table 3) could no longer be observed in the presence of liposomes (Fig. 7, Table 6). 'The H8, H7 and H9' protons are directly linked to carbon atoms, respectively, C8, C7 and C9. Yamasaki \& Bacon (1991) have presented the possible conformations for the $\mathrm{C} 7$ and $\mathrm{C} 8$ carbons, and noted that the proposed conformations are possible only for the gauche orientations of the $\mathrm{H} 7$ and $\mathrm{H} 8$ protons. Similar conclusions have been drawn by Brisson et al. (1992), they performed the calculations to determine the size of the rotational barriers for the $\mathrm{C} 7-\mathrm{C} 8$ bond. The observed differences between the ${ }^{1} \mathrm{H}^{1} \mathrm{H}$ ROESY spectra of free and liposome bound SA may be a consequence of a changed orientation of the pyranose ring from trans to gauche in the presence of liposomes.

Only one cross-peak between SA and PC molecules, i.e., $\mathrm{NHCOCH}_{3} /-\left(\mathrm{CH}_{2}\right)_{\mathrm{n}}$ was recorded in the ${ }^{1} \mathrm{H}^{1} \mathrm{H}$ ROESY spectrum of the PC liposomes in the presence of SA (Fig. 7, Table 6). This result demonstrates that SA molecules interact by dipolar way with the phospholipids methylene tail. The sialic acid penetrate into the lipid bilayer to a sufficient depth to allow the dipole interaction. The number of couplings is reflected by the width of a cross-peaks in 2D spectra (Yokono et al., 1989). The broader the cross-peak, the stronger the coupling between the protons. The width of the cross-peak $\mathrm{NHCOCH}_{3} /-\left(\mathrm{CH}_{2}\right)_{\mathrm{n}}$ is less than that at the $-\left(\mathrm{CH}_{2}\right)_{\mathrm{n}} /-$ $\mathrm{CH}_{3},-\mathrm{CH}_{2}-\mathrm{N}^{+} /-\mathrm{N}^{+}\left(\mathrm{CH}_{3}\right)_{3}, \mathrm{H} 3 \mathrm{e} / \mathrm{H} 3 \mathrm{a}, \mathrm{H} 4 / \mathrm{H} 3 \mathrm{e}$ and $\mathrm{H} 7 /$ $\mathrm{H} 4$ cross-peaks. It means that the distance between the methyl protons of the Ac group of SA and the methylene protons of the fatty acid chains is longer and the coupling between the interacting protons weaker. The present result that the cross-peak was found only between the methyl protons from the Ac group of SA and the methylene tail of the PC in ${ }^{1} \mathrm{H}^{1} \mathrm{H}$ ROESY spectrum indicates that the opposite end of the SA molecule stays in the aqueous phase without interacting with the membrane molecules.

\section{Acknowledgements}

We thank M. Potrzebowski and his coworkers S. Kaźmierski and S. Olejniczak for the obtaining the 2D NMR spectra.

\section{REFERENCES}

Barry GT, Goebel WF (1957) Colominic acid, a substance of bacterial origin related to sialic acid. Nature 179: 206-207.

Berquand A, Mingeot-Leclerq M-P, Dufrene YE (2004) Real-time imaging of drug-membrane interactions by atomic force microscopy. Biochim Biophys Acta 1664: 198-205.

Bondioli L, Costantino L, Ballestrazzi A, Lucchesi D, Boraschi D, Pellati F, Benvenuti S, Tosi G, Vandelli M (2010) PLGA nanoparticles surface decorated with the sialic acid, N-acetylneuraminic acid. Biomaterials 31: 3395-3403.

Bonechi C, Ristori S, Martini G, Martini S, Rossi C (2009) Study of bradykinin conformation in the presence of model membrane by Nuclear Magnetic Resonance on molecular modeling. Biochim Biophys Acta 1788: 708-716.

Bonfanti L (2006) PSA-NCAM in mammalian structural plasticity and neurogenesis. Progress Neurobiol 80: 129-164.

Box A, Grzesiek S (1996) ROESY. In Encyclopedia of Nuclear Magnetic Resonance. Grant DN, Harris RK, eds, pp 4789-4804. JOHN WILEY \& SONS, West Sussex.

Brinkman-Van der Linden ECM, Sonnenburg JL, Varki A (2002) Effect of sialic acid substitutions on recognition by Sambucus nigra agglutinin and Maackia amurensis hemagglutinin. Anal Biochem 303: 98-104.

Brisson J-R, Baumann H, Imberty A, Pérez S, Jennings HJ (1992) Helical epitope of the group B meningococcal $\alpha(2-8)$-linked sialic acid polysaccharide. Biochemistry 31: 4996-5004.
Byrne B, Donohoe GG, O’Kennedy R (2007) Sialic acids carbohydrate moieties that influence the biological and physical properties of biopharmaceutical proteins and living cells. Drug Discovery Today 12: 319-326.

Canet D, Robert JB (1995) Timescales in NMR: Relaxation phenomena in relaxation with molecular reorientation. In Dynamics of solutions and fluid mixtures by NMR. Delpuech J-J, ed, pp 345-396. JOHN WILEY \& SONS, New York.

Friebolin H (1990) Basic one- and two-dimensional NMR spectroscopy. WILEY-VCH, Weinheim.

Gabrielska J, Gruszecki WI (1996) Zeaxanthin (dihydroxy- $\beta$-carotene) but not $\beta$-carotene rigidifies lipid membranes: a ${ }^{1} \mathrm{H}$-NMR study of carotenoid-egg phosphatidylcholine liposome. Biochim Biophys Acta 1285: 167-174.

Hartlieb S, Günzel A, Gerardy-Schahn R, Münster-Kühnel AK, Kirschning A. Dräger G (2008) Chemoenzymatic synthesis of CMP-N-acetyl-7-fluoro-7-deoxy-neuraminic acid. Carbobydrate Res 343: 2075-2082.

Hidari KIPJ, Oyama K-I, Ito G, Nakayama M, Inai M, Goto S, Kanai Y, Watanabe K-I, Yoshida K, Futura T, Kan T, Suzuki T (2009) Identification and characterization of flavonoids as sialyltransferase inhibitors. Biochem Biophys Res Commun 382: 609-613.

Horstkorte R, Mühlenhoff M, Reutter W, Nöhring S, ZimmermannKordmann M, Gerardy-Schahn R (2004) Selective inhibition of polysialyltransferase ST8SiaII by innatural sialic acids. Exp Cell Res 298: 268-274.

Inayat-ur-Rahman, Malik SA, Bashir M, Khan R, Iqbal M (2009) Serum sialic acid changes in non-insulin-dependant diabetes mellitus (NIDDM) patients following bitter melon (Momordica charantia) and rosiglitazone (Avandia) treatment. Phytomedicine 16: 401-405.

Janiak-Osajca A, Timoszyk A (2012) Application of ${ }^{1} \mathrm{H}$ and ${ }^{31} \mathrm{P}$ NMR to topological description of a model of biological membrane fusion. Acta Biochim Pol 59: 219-224.

Jeżowska I, Wolak A, Gruszecki WI, Strzałka K (1994) Effect of $\beta$ carotene on structural and dynamic properties of model phosphatidylcholine membranes. II. A ${ }^{31} \mathrm{P}$ and ${ }^{1} \mathrm{H}-\mathrm{NMR}$ study. Biochim Biophys Acta 1194: 143-148.

Kaatze U, Göpel KD, Pottel R (1985) Zwitterion motions of differently aggregated phospholipids in aqueous and methanolic solution. A dielectric relaxation study. I Phys Chem 89: 256-2571.

Kadkhodaei M, Rivas O, Tan M, Mohebbi A, Shaka AJ (1991) Broadband homonuclear cross polarization using flip-flop spectroscopy. J Magnetic Res 91: 437-443.

Klösgen B, Reichle C, Kohlsmann S, Kramer KD (1996) Dielectric spectroscopy as a sensor of membrane headgroup mobility and hydration. Biophysical J 71: 3251-3260.

Kuczera J, Gabrielska J, Kral TE, Przestalski S (1997) A synergistic effect of select organotin compounds and ionic surfactants on liposome membranes. Appl Organic Chem 11: 591-600.

Latanowicz L, Medycki W, Jakubas R (2011) Complex molecular dynamics of $\left(\mathrm{CH}_{3} \mathrm{NH}_{3}\right)_{5} \mathrm{Bi}_{2} \mathrm{Br}_{11}$ (MAPBB) protons from NMR relaxation and second moment of NMR spectrum. J Magnetic Res 211: 207-216

Leal L, Rögnvaldsson S, Fossheim S, Nilssen EA, Topgaard D (2008) Dynamic and structural aspects of PEGylated liposomes monitored by NMR. I Colloid Interface Sci 325: 485-493.

Lindberg G (2007) Resialylation of sialic acid deficit vascular endothelium circulating cells and macromolecules may counteract the development of atherosclerosis: a hypothesis. Atherosclerosis 192: 243-245.

Lindman B, Olsson U, Söderman O (1995) Surfactant solutions: aggregation phenomena and microheterogenity. In Dynamics of solutions and fluid mixtures by NMR. Delpuech J-J, ed, pp 345-396. John Wiley \& Sons, New York.

Marcotte I, Separovic F, Anger M, Gagné S (2004) A multidimensional ${ }^{1} \mathrm{H}-\mathrm{NMR}$ investigation of the conformation of Methionine - Enkephalin in fast-tumbling bicells. Biophysics J 86: 1587-1600.

McGuire EJ, Binkley SB (1964) The structure and chemistry of colominic acid. Biochemistry 3: 247-251.

Morita S, Shimanouchi T, Sasaki H, Umakoshi H., Kuboi R (2003) Detection of heat stress mediated interaction between protein and phospholipid membrane with dielectric measurement. J Biosci Bioeng 95: 252-256.

Murphy JA, Nickerson PEB, Clarke DB (2007) Injury to retinal ganglion cell axons increases polysialylated neural cell adhesion molecule (PSA-NCAM) in the adult rodent superior colliculus. Brain Res 1163: 21-32.

Pentak D, Sułkowska A, Sułkowski WW (2008) Application of NMR and UV spectroscopy in the study of interactions between anticancer drugs and their phospholipids carriers. J Mol Struct 887: 187-193.

Pohle W, Gauger DR, Bohl M, Mrazkova E, Hobza P (2004) Lipid hydration: headgroup $\mathrm{CH}$ moieties are involved in water binding. Biopolymers 74: 27-31.

Potrzebowski MJ, Kaźmierski S, Michalska M, Olejniczak S, Ciesielski W (2001) Investigation of structure and motional behavior $1,6: 3,4$-dianhydro-2-O-tosyl- $\beta$-D-galactopyranose in solution by means multiple-field NMR spectroscopy. J Mol Struct 597: 7-19. 
Pozo Navas B, Lohner K, Deutsch G, Sevcsik E, Riske KA, Dimova R, Garidel P, Pabst G (2005) Composition dependence of vesicle morphology and mixing properties in a bacterial model membranes system. Biochim Biophys Acta 1716: 40-48.

Rutishauser U (1998) Polysialic acid at the cell surface: biophysics in service of cell interactions and tissue plasticity. J Cellular Biochem 70: 304-312.

Sabín J, Prieto G, Ruso JM, Hidalgo-Álvarez R, Sarmiento F (2006) Size and stability of liposomes: A possible role of hydration and osmotic forces. Eur Phys Jo E 20: 401-408.

Schauer R (1982) Chemistry, metabolism and biological functions of sialic acids. Adv Carbohydrate Chem Biochem 40: 131-234.

Schauer R (2004a) Sialic acids: fascinating sugars in higher animals and man. Zoology 107: 49-64.

Schauer R (2004b) Victors Ginsburg's influence on my research of the role of sialic acids in biological recognition. Arch Biochem Biophys 426: 132-141.

Schleucher J, Quant J, Glaser SJ, Griesinger C (1996) TOCSY in ROESY \& ROESY In TOCSY. In Encyclopedie of Nuclear Magnetic Resonance. Grant DN, Harris RK, eds, pp 4789-4804. John Wiley \& Sons, West Sussex.

Seidenfaden R, Krauter A, Schertzinger F, Gerardy-Schahn R (2003) Polysialic acid directs tumor cell growth by controlling heterophilic Neural Cell Adhesion Molecule interactions. Mol Cell Biol 23: 59085918.

Shimanouchi T, Sasaki M, Hiroiwa A, Yoshimoto N, Miyagawa K, Umakoshi H, Kuboi R (2011) Relationship between the mobility of phosphocholine headgroups of liposomes and the hydrophobic at membrane interface: A characterization with spectrophotometric measurements. Colloids and Surfaces B: Biointerfaces 88: 221-230.

Smith G, Shekunov BY, Shen J, Duffy AP, Anwar J, Wakerly MG, Chakrabarti R (1996) Dielectric analysis of phosphorylcholine head group mobility in egg lecithin liposomes. Pharm Res 13: 1181-1185.
Tan O, Fadiel A, Chang A, Demir N, Jeffrey R, Horvath T, GarciaSegura L-M, Naftolin F (2009) Estrogens regulate posttranslational modification of Neural Cell Adhesion Molecule during the estrogeninduced gonadotropin surge. Endocrynology 150: 2783-2790.

Timoszyk A, Gdaniec Z, Latanowicz L (2004) The effect of polysialic acid on molecular dynamics of model membranes studied by ${ }^{31} \mathrm{P}$ NMR spectroscopy. Solid State NMR 25: 142-145.

Timoszyk A, Janas T (2003) Effect of sialic acid polymers on dynamic properties of lecithin liposomes modified with the cationic octadecylamine. Mol Physics Rep 37: 67-70.

Walde P, Blochliger E (1997) Circular dichroic properties of phosphatidylcholine liposomes. Langmuir 13: 1668-1671.

Wang B (2009) Sialic acid is an essential nutrient of brain development and cognition. Ann Rev Nutrition 29: 177-183.

Wenk RW, Seelig J (1998) Proton induced vesicle fusion and the isothermal $\mathrm{L}_{\alpha} \rightarrow \mathrm{H}_{\mathrm{II}}$ phase transition of lipid bilayers: a ${ }^{31} \mathrm{P}-\mathrm{NMR}$ and titration calorimetry study. Biochim Biophys Acta 1372: 227-236.

Yamamoto I, Konto A, Handa T, Mivajima K (1995) Regulation of phospholipase D activity by neutral lipids in egg-yolk phosphatidylcholine small unilamellar vesicles and by calcium ion in aqueous medium. Biochim Biophys Acta 1233: 21-26.

Yamasaki R (1988) 2D NMR analysis of group B capsular polysaccharide of N. Meningitidis complete assignment of ${ }^{1} \mathrm{H}-\mathrm{NMR}$ spectrum of B polysaccharide of strain. Biochim Biophys Res Commun 154: 159-164.

Yamasaki R, Bacon B (1991) Three-dimensional structural analysis of the group B polysaccharide of Nesseria meningitides 6275 by two-dimensional NMR. Biochemistry 30: 851-857.

Yokono S, Ogli K, Miura S, Ueda I (1989) $400 \mathrm{MHz}$ two-dimensional nuclear Overhauser spectroscopy on anesthetic interaction with lipid bilayer. Biochim Biophys Acta 982: 300-302. 